\title{
Secondary Dentin as an Aid in Gender Predilection: A Forensic Study
}

\author{
Himanshu Singh ${ }^{1}$ Vedant Patel ${ }^{2}$ Rahul A. Razdan ${ }^{2}$ \\ ${ }^{1}$ Department of Oral Pathology and Microbiology, Index Institute of \\ Dental Sciences, Indore, Madhya Pradesh, India \\ 2 Department of Prosthodontics and Crown and Bridge and \\ Implantology, Index Institute of Dental Sciences, Indore, Madhya \\ Pradesh, India \\ ${ }^{3}$ Department of Pedodontics and Preventive Dentistry, Index \\ Institute of Dental Sciences, Indore, Madhya Pradesh, India \\ ${ }^{4}$ Department of Oral Pathology and Microbiology, M. M. College of \\ Dental Sciences and Research, M. M (Deemed to be university), \\ Mullana, Haryana, India
}

Dent J Adv Stud 2021;9:147-150.
Deepak Jha ${ }^{3}$ Prachi Nayak ${ }^{4}$ Sushruth Nayak ${ }^{4}$

Address for correspondence Himanshu Singh, MDS, Department of Oral Pathology and Microbiology, Index Institute of Dental Sciences, Indore, Madhya Pradesh, 452016, India (e-mail: himanshustar3g@gmail.com).

\begin{abstract}
Keywords

- secondary dentin

- forensic odontology

- gender predilection
\end{abstract}

Background Forensic odontology deals with age, sex, and race determination of the deceased at crime scenes, disasters, or natural calamities. Studies regarding the role of secondary dentin in age estimation have been documented on a several occasions in the literature but use of secondary dentin in gender predilection has not yet been documented. So, the present study was aimed at using the secondary dentin as a diagnostic tool in gender predilection.

Materials and Methods The study included a total of 20 samples (10 males and 10 females). Extracted teeth were collected and placed in $10 \%$ neutral buffered formalin solution. The sections were ground on Arkansas stone until the appropriate thickness of the ground sections was achieved. The freshly prepared ground section was mounted on a slide using DPX mounting media. Ground sections were visualized under a microscope and the thickness of secondary dentine was measured using the image analysis software.

Results The data were collected and subjected to group statistics. The secondary dentin thickness of all the samples, males and females, was measured. It was observed in our study that the mean thickness of secondary dentin was more in male samples (0.2970) with the standard deviation of 0.01494 , as compared with that of females where the mean thickness was found to be 0.1970 with the standard deviation of 0.02058 .

Conclusion This study has shown that variation in secondary dentin thickness does exist between male and female groups. This criterion can be considered as an aid for gender determination in the future. published online November 10, 2021
DOI https://doi.org/ $10.1055 / \mathrm{s}-0041-1736488$. ISSN 2321-1482.
(C) 2021. Bhojia Dental College and Hospital affiliated to Himachal Pradesh University. All rights reserved.

This is an open access article published by Thieme under the terms of the Creative Commons Attribution-NonDerivative-NonCommercial-License, permitting copying and reproduction so long as the original work is given appropriate credit. Contents may not be used for commercial purposes, or adapted, remixed, transformed or built upon. (https://creativecommons.org/ licenses/by-nc-nd/4.0/)

Thieme Medical and Scientific Publishers Pvt. Ltd., A-12, 2nd Floor, Sector 2, Noida-201301 UP, India 


\section{Introduction}

According to Keiser-Neilson, forensic odontology is defined as the branch of forensic medicine, which in the interest of justice deals with the proper handling and examination of dental evidence, with proper evaluation and presentation of the dental findings. ${ }^{1}$ The word "forensic" has been derived from the Latin, which means "to the forum." Forensic odontology deals with the examination and evaluation of various dental evidence during civil or criminal proceedings in the interest of justice. Moreover, it helps in the establishment of the identity of the living as well as the dead person. ${ }^{2,3}$ Forensic odontology deals with age, sex, and race determination of the deceased at crime scenes, disasters, or natural calamities.

Forensic odontologists help various legal authorities by various means such as: ${ }^{4}$

$>$ Management and maintenance of dental records.

$>$ Identification of human remains by comparing antemortem and postmortem dental information.

$>$ Collection and analysis of patterned marks (bite marks) on inanimate objects or tissue surface.

$>$ Recognition of the signs and symptoms of human abuse.

$>$ Presentation of dental evidence as an expert witness in identification, bite marks, human abuse, malpractice fraud, and personal injury cases.

$>$ Assessment of person's age.

$>$ Determination of sex.

Teeth, being the hardest and chemically stable structure in the human body, are valuable material for genetic, anthropology, and forensic investigations. ${ }^{5}$ Therefore, the tooth is considered as an important source of dental identification when there is no other evidence available. Number of characteristic features of the teeth and their associated structures will provide the identity of a person, which forms the basis of their identification providing information regarding an individual.

Moreover, the identification of a person can be done by sex age, race, communal characters, scars, tattoo, hair, any deformity, anthropometry, and dactylography. ${ }^{6}$

There are various methods available for gender determination, attributed to oral structures. These include:

$>$ Canine dimorphism.

$>$ Root length determination.

$>$ Odontometric differences.

$>$ Tooth size.

$>$ Barr bodies from buccal smears and pulpal tissues.

$>$ Enamel protein.

Genetic analysis using polymerase chain reaction has been used to estimate sex/gender that includes long bones of the arm, ${ }^{7}$ femoral head,${ }^{8}$ metatarsals, ${ }^{9}$ patellae, ${ }^{10}$ humerus, ${ }^{11}$ footprint ratio, ${ }^{12}$ radial, and ulnar bone lengths. ${ }^{13}$

The tooth is the hardest structure in the human body and contains enamel, dentin, cementum, and pulp. Three types of dentin have been identified in human teeth: primary, secondary, and tertiary dentin. Secondary dentin is the dentin formed continuously throughout life after the crown is fully formed. Formation of secondary dentin starts at the pulp periphery when related to age and masticatory change. ${ }^{14-16}$

\section{Materials and Methods}

The study included a total of 20 samples, out of which 10 samples were obtained from male subjects and 10 from female subjects. Subject's basic information such as chronological age, sex, and the tooth that has to be extracted was noted down before extraction of tooth. Inclusion criteria were periodontally compromised teeth indicated for extraction. Extracted teeth were collected and placed in a $10 \%$ neutral buffered formalin solution. They were then reduced mesiodistally on a lathe machine. These sections were then ground on Arkansas stone until the appropriate thickness of the ground sections was achieved. The freshly prepared ground section was mounted on a slide using DPX mounting media and covered using a glass coverslip. Ground sections were visualized under Nikon research microscope (Eclipse80i) at 40x magnification and the thickness of secondary dentine was measured using the image analysis software; Nis-element, basic research, version 2.32 (Windows XP).

\section{Results}

The data were collected ( - Table $\mathbf{1}$ ) and subjected to group statistics. The secondary dentin thickness of all the samples, males (-Fig. 1) and females (-Fig. 2), was measured. It was observed in our study that the mean thickness of secondary dentin was more in male samples (0.2970) with the standard deviation of 0.01494 , as compared with that of females where the mean thickness was found to be 0.1970 with the standard deviation of 0.02058 (-Table 2).

\section{Discussion}

We all are aware that dental tissues are known as one of the most lasting and reliable human body tissues, which is

Table 1 Values of thickness of secondary dentin (in millimeters)

\begin{tabular}{|l|l|l|}
\hline SI. no. & $\begin{array}{l}\text { Thickness in } \\
\text { males }\end{array}$ & $\begin{array}{l}\text { Thickness in } \\
\text { females }\end{array}$ \\
\hline 1 & 0.32 & 0.17 \\
\hline 2 & 0.30 & 0.19 \\
\hline 3 & 0.31 & 0.21 \\
\hline 4 & 0.30 & 0.23 \\
\hline 5 & 0.29 & 0.20 \\
\hline 6 & 0.30 & 0.19 \\
\hline 7 & 0.28 & 0.17 \\
\hline 8 & 0.29 & 0.22 \\
\hline 9 & 0.31 & 0.18 \\
\hline 10 & 0.27 & 0.21 \\
\hline
\end{tabular}




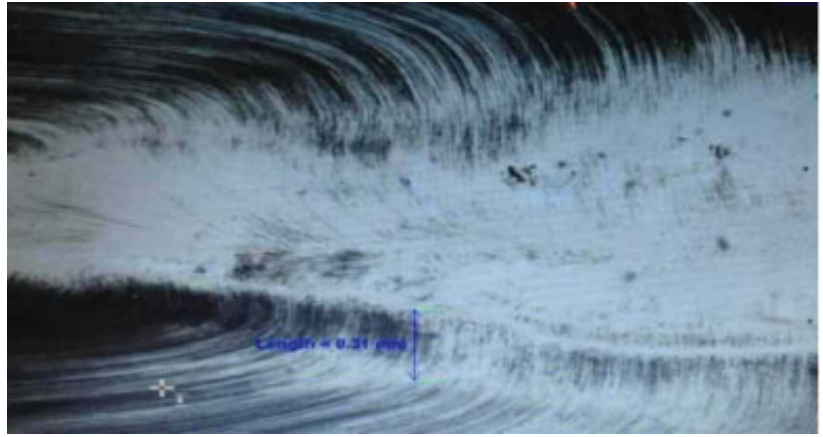

Fig. 1 Thickness (in millimeters) of secondary dentin in male (40 $\times$ magnification).

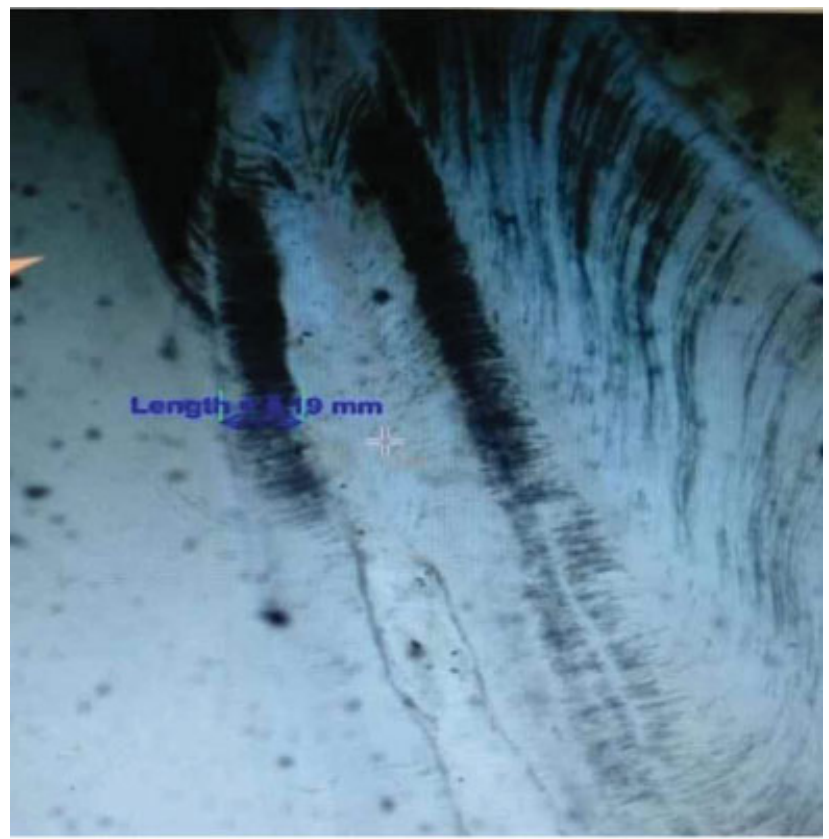

Fig. 2 Thickness (in millimeters) of secondary dentin in female (40 $\times$ magnification).

resistant to distinctive external consequences as well as thermal, mechanical, or chemical irritations. They are found very competent in various odontological, anthropological, and forensic studies because of the fact that they may be preserved for a prolonged time even after death. ${ }^{17}$

In the human body, a tooth is the hardest structure. It consists of enamel, dentin, cementum, and pulp. Dentin is present under enamel and accounts for a whole tooth root. There are three types of dentin: primary, secondary, and tertiary. Out of these three types, secondary dentin is the only dentin that is formed uninterruptedly throughout life. ${ }^{18,19}$

Various researches have been done regarding secondary dentin. In a study done by Gottleib, it was observed that secondary dentin will change with age. ${ }^{20}$ In another study, Gustafson incorporated the secondary dentin as one of the parameters and presented his age estimation formula. ${ }^{21}$ In 1992, Solheim also presented an age estimation formula using secondary dentin as one of the parameters. $^{15}$
Table 2 Mean and standard deviation for thickness of secondary dentin

\begin{tabular}{|l|l|l|l|l|}
\hline & $\boldsymbol{n}$ & Mean & SD & SE \\
\hline Male & 10 & 0.2970 & 0.01494 & 0.00473 \\
\hline Female & 10 & 0.1970 & 0.02058 & 0.00651 \\
\hline
\end{tabular}

Abbreviations: SD, standard deviation; SE, standard error.

In a study conducted by Rao and Kotian, it was observed that the mesiodistal width of mandibular canines was seen remarkably greater in males as compared with females. ${ }^{22}$ Das et al in their study observed that gender determination can be done even 4 weeks after the death, from the study of chromosomes $\mathrm{X}$ and $\mathrm{Y}^{23}$

In another study done by Whittaker et al, they determined the gender from necrotic pulp tissue. This tissue was stained by quinacrine mustard using fluorescent y chromosome. ${ }^{24}$ Sivagami et $\mathrm{al}^{25}$ in their research where DNA was prepared from the teeth by ultrasonication and polymerase chain reaction amplification came up with a $100 \%$ favorable outcome in gender determination of an individual.

But till now in the literature, no study has been done regarding the role of secondary dentin in gender determination. So, keeping this fact in mind, we have done the present study, where we included 10 ground sections of male and female each and studied the thickness of secondary dentin using the image analysis software. We found that the mean thickness of secondary dentin is more in males as compared with that of females. This finding was statistically highly significant. Thus, our study gave an indication that the secondary dentin can be used as an aid for gender determination by measuring its thickness.

\section{Conclusion}

The secondary dentin has been used as criterion for age estimation till today. This was a small attempt made by us to find its validity in gender predilection. The study has shown that variation in secondary dentin thickness does exist between male and female groups. This criterion can be considered as an aid for gender determination in the future. Study groups could have been age-wise for better evaluation since the secondary dentin is deposited after root completion or adolescent age. So, an extensive research using more sample size may be required to substantiate the statements of this study and to apply our study method in the future.

\section{Source of Support}

Nil.

Conflict of Interest

None declared.

\section{References}

1 Keiser NS. Person Identification by Means of Teeth. 1st edition. Bristol: John Wright and Sons; 1980:190-225

2 Cameron JM, Sims BG. Forensic Dentistry. 1st edition. Edinburgh: Churchill Livingstone; 1974:310-403 
3 Neville BW, Damm DD, Allen CM, Bouquot JE. Oral and Maxillofacial Pathology. 2nd edition. Philadelphia (PA): W.B. Saunders Co; 2002:201-209

4 Neville BW, Damm DD, Allen CM, Bouquot JE. Oral and Maxillofacial Pathology. 3rd edition. New Delhi: Elsevier; 2009:113-119

5 Kaushal S, Patnaik VVG, Agnihotri G. Mandibular canine in sex determination. J Anat Soc India 2003;52(02):119-124

6 Wadhwan V, Urs AB, Manchanda A. Sex determination using three methodologies as a tool in forensic dentistry. J Indian Dent Assoc 2011;5:77-80

7 Mall G, Hubig M, Büttner A, Kuznik J, Penning R, Graw M. Sex determination and estimation of stature from the long bones of the arm. Forensic Sci Int 2001;117(1-2):23-30

8 Purkait R. Sex determination from femoral head measurements: a new approach. Leg Med (Tokyo) 2003;5(1, Suppl 1): S347-S350

9 Robling AG, Ubelaker DH. Sex estimation from the metatarsals. J Forensic Sci 1997;42(06):1062-1069

10 Kemkes-Grottenthaler A. Sex determination by discriminant analysis: an evaluation of the reliability of patella measurements. Forensic Sci Int 2005;147(2-3):129-133

11 Işcan MY, Loth SR, King CA, Shihai D, Yoshino M. Sexual dimorphism in the humerus: a comparative analysis of Chinese, Japanese and Thais. Forensic Sci Int 1998;98(1-2):17-29

12 Rao NG, Kotian MS. Foot print ration (FPR)- a clue for establishing sex identity. J Indian Acad Forensic Med 1990;2(02):51-56

13 Celbis O, Agritmis H. Estimation of stature and determination of sex from radial and ulnar bone lengths in a Turkish corpse sample. Forensic Sci Int 2006;158(2-3):135-139
14 Das N. Sex determination from pulpal tissue. J Indian Acad Forensic Med 2004;26:971-973

15 Solheim T. Amount of secondary dentin as an indicator of age. Scand J Dent Res 1992;100(04):193-199

16 Willems G. A review of the most commonly used dental age estimation techniques. J Forensic Odontostomatol 2001;19(01):9-17

17 Soomer H, Ranta H, Lincoln MJ, Penttilä A, Leibur E. Reliability and validity of eight dental age estimation methods for adults. J Forensic Sci 2003;48(01):149-152

18 Maples WR. An improved technique using dental histology for estimation of adult age. J Forensic Sci 1978;23(04):764-770

19 Amandeep S, Goria RK. Age estimation by Gustafson's method and its modifications. J Indopacific Acad Forensic Odontol 2010;1:12-19

20 Brkić H, Miličević M, Petrovečki M. Forensic determination of dental age of adults. Acta Stomatol Croat 2008;42:267-272

21 Gustafson G. Age determination on teeth. J Am Dent Assoc 1950; 41(01):45-54

22 Rao NG, Rao NN, Pai ML, Kotian MS. Mandibular canine index-a clue for establishing sex identity. Forensic Sci Int 1989;42(03): 249-254

23 Das N, Gorea RK, Gargi J, Singh JR. Sex determination from pulpal tissue. J Indian Acad Forensic Med 2004;26:122-125

24 Whittaker DK, Llewelyn DR, Jones RW. Sex determination from necrotic pulpal tissue. Br Dent J 1975;139(10):403-405

25 Sivagami AV, Rao AR, Varshney U. A simple and cost-effective method for preparing DNA from the hard tooth tissue, and its use in polymerase chain reaction amplification of amelogenin gene segment for sex determination in an Indian population. Forensic Sci Int 2000;110(02):107-115 